\title{
IDENTIFIKASI PENYALAHGUNAAN PERUNTUKAN RUANG TERBUKA HIJAU PADA PEMBANGUNAN KAWASAN KULINER DI PLUIT JAKARTA UTARA
}

Almira Muthi Faliha, Annisa Aulia Suwandi, Dewi M Z S Pertiwi, Dedi Hantono*

Program Studi Arsitektur, Universitas Muhammadiyah Jakarta

Email: dedihantono@umj.ac.id

The increasing demand for space, especially for settlements and built-up land, has an impact on the declining environmental quality of the area. The Spatial Plan that has been made is not able to prevent land conversion in urban areas so that the existence of Green Open Space (RTH) is increasingly threatened and the city is increasingly uncomfortable for activities, especially for joint activities. This study will discuss the "Identification of the Use of Green Open Land for the Development of Culinary Areas in Pluit, North Jakarta". The purpose of this study is to determine the availability of green open space in North Jakarta, as well as to find out the existence of matters concerning the misuse of green open space in Pluit, North Jakarta based on local regulations governing Green Open Space. The method used in this analysis is a qualitative descriptive method with data collection techniques in the form of secondary data. Based on the results of the study, it can be seen that the availability of green open land in North Jakarta is only about $5 \%$ of the total area, this percentage is still far from meeting the provisions of the law which stipulates that the proportion of green open space in urban areas must reach 30\%. The development of the culinary area in Pluit has several violations such as Law Number 26 of 2007 concerning Spatial Planning, which only provides $11 \%$ open space, Regional Regulation no. 8 of 2007 concerning Public Order in DKI Jakarta in article 36, because it builds a culinary area adjacent to the High Voltage Air Line (SUTET) and there are buildings that stand on Green Open Land.

\section{Keywords: Region, Culinary, Environment, Development, Open Space}

Semakin meningkatnya permintaan akan ruang khususnya untuk permukiman dan lahan terbangun berdampak kepada semakin merosotnya kualitas lingkungan pada daerah tersebut. Rencana Tata Ruang yang telah dibuat tidak mampu mencegah alih fungsi lahan di perkotaan sehingga keberadaan Ruang Terbuka Hijau (RTH) semakin terancam dan kota semakin tidak nyaman untuk beraktivitas terutama untuk aktivitas bersama. Penelitian ini akan membahas mengenai "Identifikasi Penyalahgunaan Peruntukan Lahan Terbuka Hijau Pasa Pembangunan Kawasan Kuliner Di Pluit Jakarta Utara". Adapun tujuan penelitian ini untuk mengetahui ketersediaan ruang terhuka hijau di Jakarta Utara, serta untuk mengetahui adanya hal-hal yang menyangkut penyalahgunaan lahan terbuka hijau di Pluit Jakarta Utara berdasarkan peraturan daerah yang mengatur tentang Ruang Terbuka Hijau. Metode yang digunakan dalam analisis ini merupakan metode deskriptif kualitatif dengan teknik pengambilan data berupa data sekunder. Berdasarkan hasil penelitian dapat diketahui bahwa ketersediaan lahan terbuka hjau di Jakarta Utara hanya sekitar 5\% dari total luasnya, presentase tersebut masih jauh dari memenuhi ketentuan undang-undang yang mengatur bahwa proporsi RTH di perkotaan harus mencapai 30\%. Pembangunan pada kawasan kuliner di pluit ini terdapat beberapa pelanggaran seperti Undang-Undang Nomor 26 Tahun 2007 tentang Penataan Ruang yaitu hanya menyediakan 11\% ruang terbuka, Peraturan Daerah No. 8 Tahun 2007 mengenai Ketertiban Umum di DKI Jakarta pada pasal 36, karena membangun kawasan kuliner yang berdekatan dengan Saluran Udara Tegangan Tinggi (SUTET) dan terdapat bangunan yang berdiri di atas Lahan Terbuka Hijau. 


\section{Kata Kunci: Kawasan, Kuliner, Lingkungan, Pembangunan, Ruang Terbuka}

\section{PENDAHULUAN}

Pertumbuhan jumlah penduduk di Jakarta mengakibatkan perubahan tata letak ruang kota yang bertambah padat. Hal tersebut menyebabkan kebutuhan ruang meningkat. Kualitas lingkungan suatu daerah akan berdampak pada semakin meningkatnya permintaan akan ruang khususnya kebutuhan akan lahan permukiman (Sari et al., 2017). Rencana Tata Ruang yang sudah ditetapkan oleh pemerintah tidak memungkiri adanya pengalihan fungsi lahan sehingga keberadaan Ruang Terbuka Hijau (RTH) semakin berkurang dan terancam yang menjadikan kota semakin tidak nyaman untuk beraktivitas baik secara personal maupun aktivitas bersama (Hantono, 2019).

Radiasi dari sinar matahari yang menyentuh permukaan akan mengalami pemantulan dan penyerapan radiasi. Semua jenis tutupan lahan memiliki nilai albedo. Albedo adalah perbandingan antara radiasi matahari yang dipantulkan kembali dengan radiasi yang datang. Semakin tinggi perbandingan antara radiasi albedo berarti semakin banyak radiasi yang dipantulkan. Sebaliknya, semakin tinggi laju serapan radiasi maka semakin tinggi radiasi yang akan dipancarkan kembali ke atmosfer, sehingga udara akan semakin hangat dan suhu udara akan meningkat (Dyah Prinajati, 2019). Menurut teori keseimbangan energi 50\% radiasi matahari mencapai permukaan bumi akan serap oleh bumi. Dari total radiasi yang diabsobsi atau di serap, lahan terbangun oleh bangunan yang menutupi lahan hijau dan tandus akan vegetasi lebih banyak menyerap radiasi daripada lahan bervegetasi.

Lokasi pusat kuliner di Jalan Pluit Karang Indah Timur yang dibangun di atas Ruang Terbuka Hijau (RTH) yang menggunakan $11 \%$ dari lahan ruang terbuka hijau tersebut dan hingga saat ini masih dilanjutkannya proyek yang melanggar tersebut. Pengendalian pemanfaatan ruang menjadi sangat penting dilakukan oleh pemerintah khususnya pemerintah daerah dalam upaya mengoptimalkan fungsi lahan sesuai dengan daya dukung lingkungan masing-masing (Hakim, 2020). Lemahnya mekanisme pengendalian pembangunan merupakan salah satu kendala dalam menerapkan rencana tata ruang di daerah. Rencana tata ruang belum menjadi pedoman dalam penyusunan kebijakan apalagi dalam perencanaan kegiatan pembangunan yang dilaksanakan setiap tahun jarang sekali memperhatikan rencana tata ruang untuk menentukan lokasi pembangunan yang tepat. Berdasarkan fenomena yang telah dijabarkan melatarbelakangi adanya penelitian mengenai identifikasi penyalahgunaan peruntukan lahan terbuka hijau pada pembangunan kawasan kuliner di Pluit Jakarta Utara sehingga muncul pertanyaan bagaimana mengetahui ketersediaan ruang terbuka hijau di Jakarta Utara serta bagaimana mengetahui penyalahgunaan ruang terbuka hijau di Pluit Jakarta Utara berdasarkan peraturan daerah yang mengatur tentang Ruang Terbuka Hijau.

\section{METODE PENELITIAN}

Pada penelitian kali ini menggunakan metode deskriptif kualitatif yang merupakan studi untuk mengetahui dan memahami pembagian lahan yang ada di DKI Jakarta, dan undang-undang penyalahgunaan lahan terbuka hijau khususnya di Pluit Jakarta Utara. Langkah yang dilakukan dalam penelitian ini yaitu dengan menggunakan data sekunder berupa studi literatur, metode ini dilakukan untuk mencari berbagai data yang 
berkaitan dengan penelitian melalui browsing data di internet, membaca buku serta jurnal (Sugiyono, 2018). Hal ini dilakukan untuk melakukan perbandingan secara tidak langsung dengan kasus serupa yang ada di Jakarta.

\section{HASIL DAN PEMBAHASAN}

Undang-Undang Nomor 26 Tahun 2007, tentang Penataan Ruang telah mengharuskan bagi setiap wilayah kota bahwa dalam rencana tata ruang wilayah kotanya diwajibkan untuk menyediakan paling sedikitnya $30 \%$ dari ruang atau wilayahnya untuk RTH, yang dibagi menjadi $20 \%$ diperuntukkan sebagai RTH publik dan $10 \%$ akan diperuntukkan sebagai RTH privat pada lahan-lahan yang dimiliki oleh swasta maupun masyarakat.

Lahan peruntukan ruang terbuka hijau merupakan hal yang berhubungan dengan penataan lahan hijau di dalam wilayah kota tersebut yang dimana terdiri dari beberapa fungsi kawasan hijau yaitu sebagai hutan kota, kawasan hijau sebagai tempat rekreasi kota, kawasan hijau untuk berkegiatan olahraga kota, kawasan hijau sebagai pemakaman, kawasan hijau sebagai lahan pertanian, kawasan hijau sebagai jalur hijau, dan kawasan hijau sebagai lahan pekarangan (Prayogi \& Hantono, 2018). Ketersediaan Ruang Terbuka Hijau (RTH) sangat penting bagi suatu kota, hal tersebut untuk mendukung keberlangsungan ekologis maupun menjamin keseimbangan ekosistem kota (Butudoka, 2005). Selain itu, RTH sangat diperlukan untuk meningkatkan ketersediaan air dan udara bersih bagi masyarakat serta menciptakan keindahan pada suatu kota (Hantono et al., 2018). Secara ekologi fungsi RTH tidak akan berguna jika tidak diimbangi dengan cara memperbaiki kualitas dan kuantitas RTH di DKI Jakarta, bahkan pesatnya laju pertumbuhan kota seringkali mengorbankan RTH sebagai fungsi yang tidak sebagaimana mestinya.

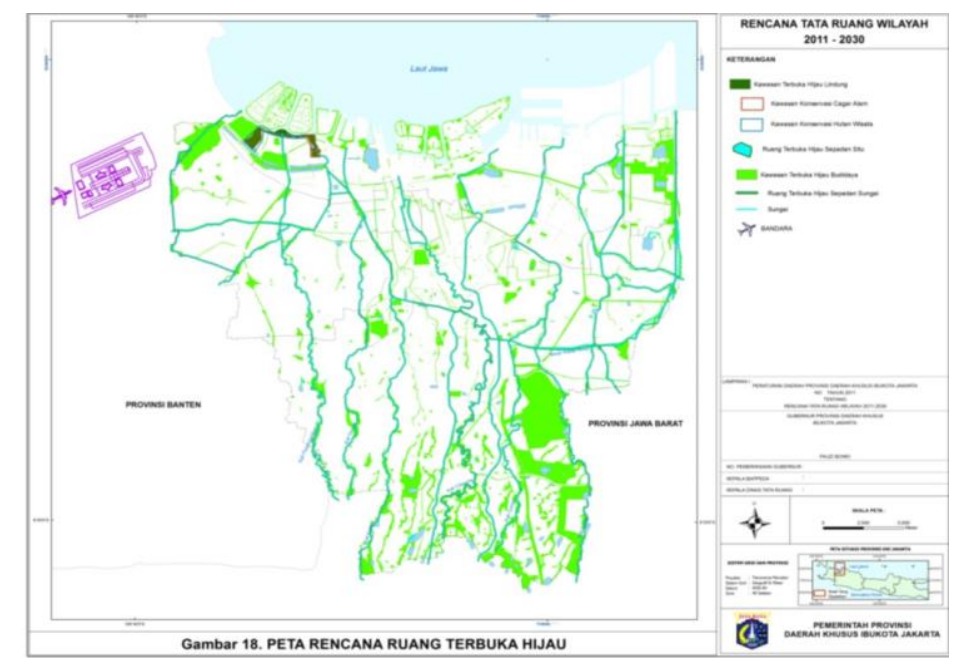

Gambar 1. Peta Rencana Ruang Terbuka Hijau DKI Jakarta

Menurut Peraturan Daerah No. 8 Tahun 2007 mengenai Ketertiban Umum di DKI Jakarta pada pasal 12 disebutkan bahwa tidak diperbolehkan mengganti atau mengalihfungsikan RTH jalur hijau maupun taman. Kemudian, pada pasal 20 menjelaskan bahwa setiap orang atau badan dilarang membangun dan/atau bertempat tinggal di jalur hijau atau taman, sementara pada pasal 36 berisi tentang setiap orang atau badan dilarang mendirikan bangunan atau membiarkan tumbuh pohon didalam kawasan Saluran Udara Tegangan Tinggi (SUTET) pada 


\section{Jurnal Potensi}

Program Studi Magister Perencanaan Wilayah Universitas Batam

Volume I, Issue 1, Maret 2021, Page 1-9

jangkauan yang sudah ditetapkan sesuai dengan ketentuan yang berlaku.

Penggunaan lahan berdasarkan Perda Provinsi DKI Jakarta No.1 Tahun 2012. klasifikasi tersebut dapat dibagi menjadi beberapa kawasan, diantaranya:

1. Kawasan Hijau Lindung

2. Kawasan Hijau Budidaya

3. Kawasan Perumahan

4. Kawasan Perumahan Taman

5. Kawasan Perkantoran, Perdagangan dan Jasa

6. Kawasan Perkantoran, Perdagangan dan Jasa Taman

7. Ruang Terbuka Biru

8. Kawasan Industri dan Pergudangan

Kawasan perdagangan dan jasa dibutuhkan untuk meningkatkan ekonomi di Provinsi DKI Jakarta. Salah satu upaya untuk meningkatkan ekonomi yaitu dengan membuat pariwisata di daerah tersebut (Sidabutar et al., 2018). Menurut Peraturan Menteri Pariwisata Nomor 3 Tahun 2018 sarana dan prasarana merupakan salah satu indikator penting dalam pengembangan pariwisata. Tersedianya kelengkapan baik secara sarana maupun prasarana tersebut akan menentukan keberhasilan suatu daerah untuk menjadi daerah tujuan wisata (Asharsinyo et al., 2019). Salah satunya yaitu pusat kuliner, merupakan fasilitas tempat kegiatan layanan jual beli makanan dan minuman. Lokasi pusat kuliner harus mempertimbangkan kesesuaian terkait tata letak yang sesuai dengan (PERDA) di daerah tersebut.

Letak pembangunan kawasan kuliner berada di Jl. Pluit Karang Indah Timur No.89, RT.6/RW.14, Pluit, Kec. Penjaringan, Kota Jkt Utara, Daerah Khusus Ibukota Jakarta 14450.

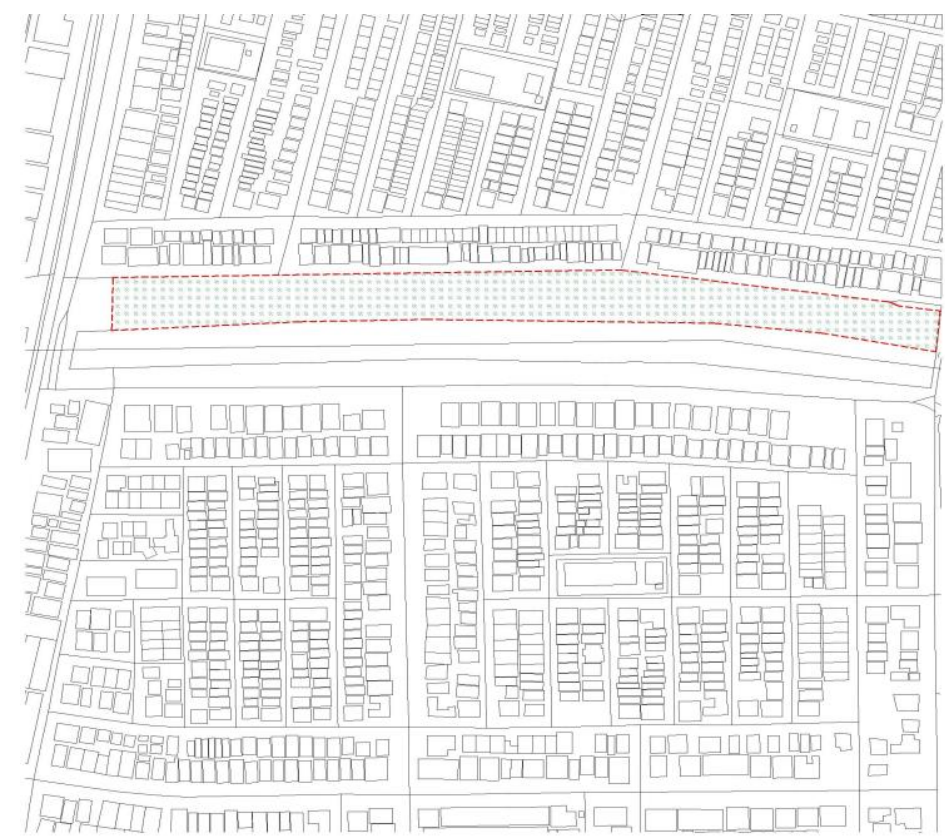

Gambar 2. Lokasi RTH

Sebelum proses pembangunan lahan untuk kawasan kuliner, lahan ini merupakan sebuah lahan terbuka hijau.
Peruntukan lahan untuk lahan ini berada di zona khusus yang diprioritaskan sebagai lahan terbuka hijau. 


\section{Jurnal Potensi}

Program Studi Magister Perencanaan Wilayah Universitas Batam

Volume I, Issue 1, Maret 2021, Page 1-9

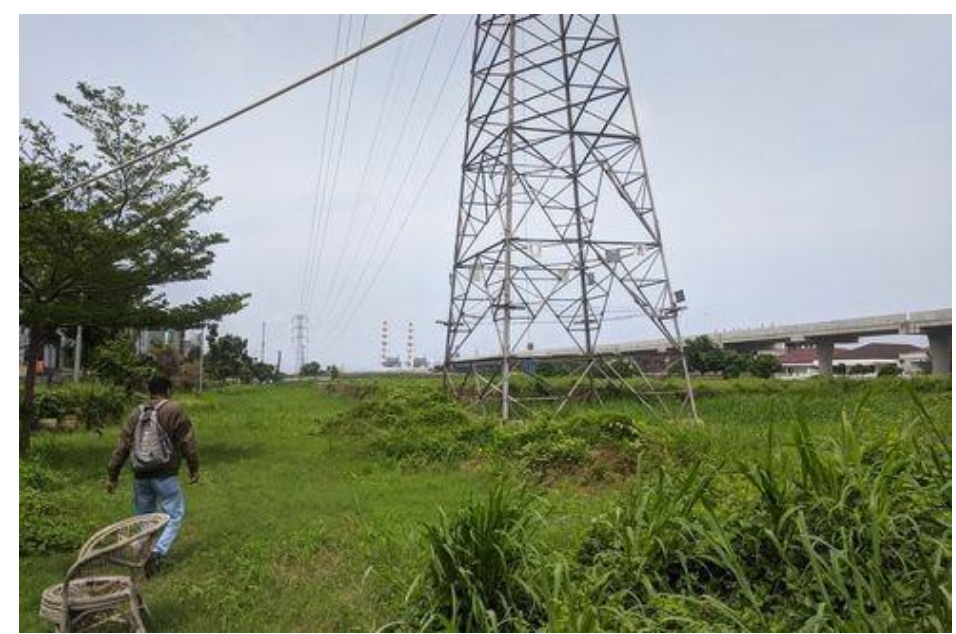

Gambar 3. RTH sebelum pembangunan

Dapat dilihat dari gambar 4 merupakan kondisi lahan setelah proses pengerjaan pembangunan kawasan kuliner pluit. Adanya gunungan pasir, tumpukan batu kali, dan tanah yang sudah diuruk terlihat di dalam area proyek. Pada dasarnya pihak DPRD meminta PT Jakarta Propertindo menghentikan proyek tersebut karena dinilai berdiri diatas zona hijau dan berdekatan dengan saluran udara tegangan ekstra tinggi (SUTET).

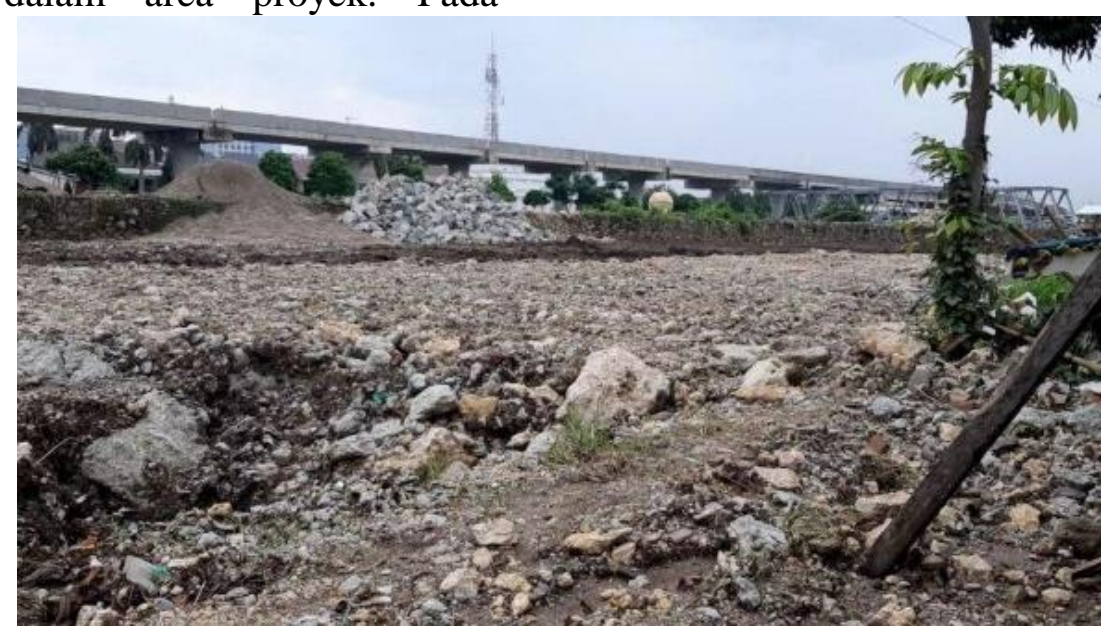

Gambar 4. Kondisi lahan saat pembangunan taman kawasan pluit.

Sumber: Azhari, 2020

Tentunya sebelum pembangunan dilakukan perlu adanya desain perencanaan yang baik dan efektif. Desain pada taman kawasan kuliner pluit. Yang dimana pembangunan dilakukan di atas lahan 2,5 hektar dengan $11 \%$ area lahan dijadikan sebagai ruang interaktif, sarana olahraga dan kuliner. Seperti adanya jogging track, taman hingga lokasi parkir. Rencananya juga RTH dapat menjadi alternatif bagi warga yang ingin menikmati beragam makanan atau melakukan olahraga ringan. 

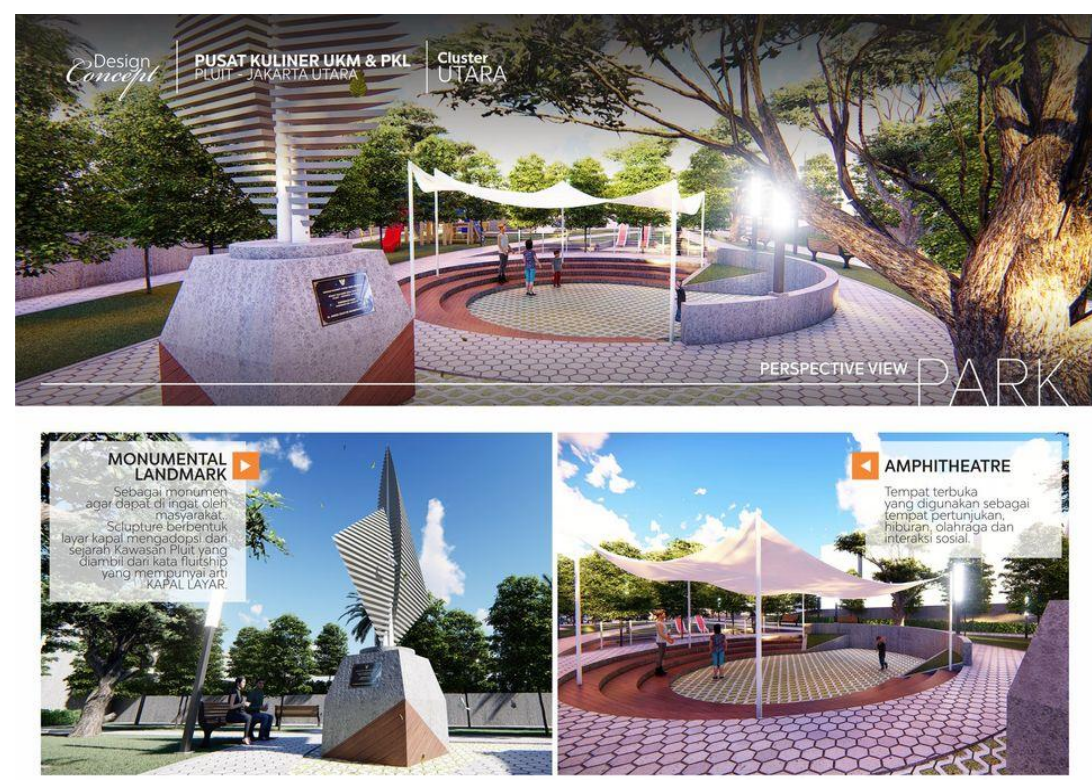

Gambar 5. Desain konsep taman kawasan pluit.

Analisis yang perlu diperhatikan untuk ruang terbuka hijau pada kawasan kuliner Jl. Pluit Karang Indah Timur No.89, RT.6/RW.14, Pluit, Kec. Penjaringan, Kota Jkt Utara, Daerah Khusus Ibukota Jakarta 14450 yaitu :

1. Sedikitnya $30 \%$ dari ruang atau wilayahnya untuk RTH. (UndangUndang Nomor 26 Tahun 2007, tentang Penataan Ruang)

2. Tidak diperbolehkan mengganti atau mengalihfungsikan RTH jalur hijau maupun taman. (Peraturan Daerah No. 8 Tahun 2007 mengenai Ketertiban Umum di DKI Jakarta pada pasal 12)

3. Setiap orang atau badan dilarang membangun dan/atau bertempat tinggal di RTH jalur hijau atau taman (Peraturan Daerah No. 8 Tahun 2007 mengenai Ketertiban Umum di DKI Jakarta pada pasal 20)

4. Setiap orang atau badan dilarang mendirikan bangunan atau membiarkan tumbuh pohon didalam kawasan Saluran Udara Tegangan Tinggi (SUTET) pada jangkauan yang sudah ditetapkan sesuai dengan ketentuan yang berlaku.tapkan (Peraturan Daerah No. 8 Tahun 2007 mengenai Ketertiban Umum di DKI Jakarta pada pasal 36).

\section{1) Ketersediaan Ruang Terbuka Hijau di Jakarta Utara}

Kawasan Kuliner Pluit terletak di bagian Utara Jakarta, tepatnya di Kec. Penjaringan, Kota Jakarta Utara. Meningkatnya kebutuhan akan penggunaan lahan tidak terlepas dari Meningkatnya aktivitas pembangunan serta perkembangan wilayah di Jakarta, khususnya Jakarta Utara. Luasan lahan yang relatif tetap tidak diimbangi dengan permintaan lahan yang terus meningkat sehingga mengakibatkan banyaknya fenomena mengenai pengalihan fungsi lahan terutama Ruang Terbuka Hijau di Kota Jakarta Utara. Berdasarkan data dari Suku Dinas Pertamanan dan Pemakaman Jakarta Utara, pada tahun 2014 Jakarta Utara hanya memiliki lahan sebesar 5\% dari total luasnya. Tentunya presentase RTH tersebut masih jauh dari memenuhi ketentuan undang-undang yang mengatur bahwa proporsi RTH di perkotaan harus mencapai $30 \%$ dari total luas perkotaan. 


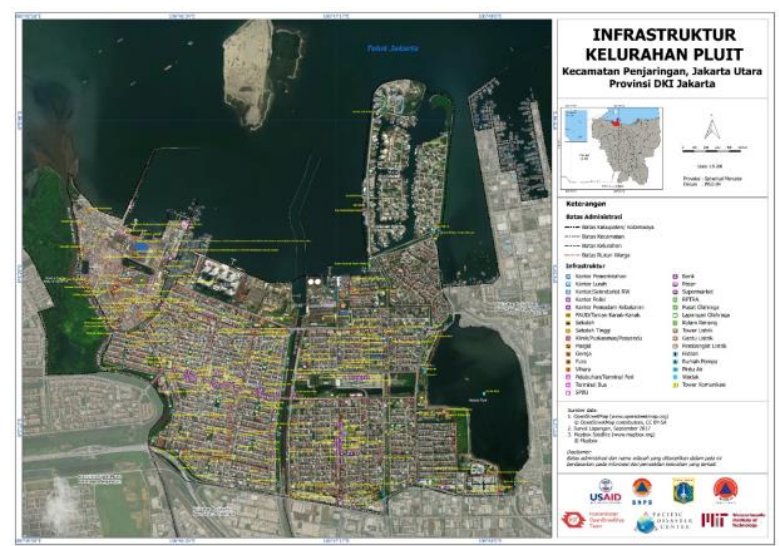

Gambar 6. Area Ruang Terbuka Hijau Kelurahan Pluit DKI Jakarta Sumber: Openstreetmap, 2020

Sedangkan yang terjadi di lokasi pembangunan kuliner yang terletak di Jl. Pluit Karang Indah Timur No.89, RT.6/RW.14, Pluit, Kec. Penjaringan, Kota Jkt Utara, Daerah Khusus Ibukota Jakarta 14450 dengan proyek seluas 2,4 hektar hanya menyisihkan $11 \%$ untuk ruang terbuka hijau (RTH), dan dari $11 \%$ ruang terbuka hijau tidak sepenuhnya untuk area hijau atau area untuk serapan berikut pembagian dari $11 \%$ adalah jogging track, taman hingga lokasi parkir.

\section{2) Analisis Ketidaksesuaian Pada Pembangunan Kawasan Kuliner Berdasarkan Peraturan Daerah}

Kawasan Kuliner di Pluit merupakan kawasan yang dalam masa pembangunannya, terdapat beberapa pertentangan dari beberapa pihak mengenai peruntukan lahan yang pada awalnya merupakan lahan peruntukan RTH (Ruang Terbuka Hijau). Untuk mengetahui penyalahgunaan lahan terbuka hijau ini, penulis melakukan beberapa analisis berdasarkan Undang - Undang dan peraturan daerah yang berkaitan dengan lahan terbuka hijau.

Berdasarkan Peraturan Daerah No. 8 Tahun 2007 mengenai Ketertiban Umum di DKI Jakarta pada pasal 12 yang menyatakan bahwa Tidak diperbolehkan mengganti atau mengalih fungsikan RTH jalur hijau maupun taman. Menurut pemerintah DKI Jakarta dalam website resminya peruntukan lahan pada kawasan kuliner Pluit ini berada di zona khusus yang diprioritaskan sebagai lahan terbuka hijau. Hal ini menjadikan adanya beberapa pertentangan yang terjadi di sekitar lingkungan pembangunan kawasan kuliner.

Berdasarkan dari Peraturan Daerah No. 8 Tahun 2007 mengenai Ketertiban Umum di DKI Jakarta pada pasal 36, dimana disebutkan bahwa dilarang untuk mendirikan bangunan diatas lahan yang diperuntukan sebagai RTH (Ruang Terbuka Hijau) atau di dalam kawasan yang berdekatan dengan Saluran Udara Tegangan Tinggi (SUTET). Kawasan ini merupakan RTH (Ruang Terbuka Hijau) yang akan dibangun menjadi kawasan kuliner yang berdekatan dengan Saluran Udara Tegangan Tinggi (SUTET). Adanya banguan di atas lahan yang terdiri dari 2 lantai. Berdasarkan data yang ada menjelaskan bahwa adanya ketidaksesuaian terhadap kawasan kuliner di pluit.

\section{KESIMPULAN}

Berdasarkan hasil penelitian dapat disimpulkan bahwa ketersediaan lahan terbuka hijau di Jakarta Utara hanya sekitar 5\% dari total luasnya. Presentase 
tersebut masih jauh dari memenuhi ketentuan undang-undang yang mengatur bahwa proporsi RTH di perkotaan harus mencapai $30 \%$. Proyek pembangunan kawasan kuliner yang berlokasi di jl pluit, jakarta utara juga telah melanggar diantaranya:

1. Ketentuan ruang terbuka yang telah ditetapkan pada (Undang-Undang Nomor 26 Tahun 2007, tentang Penataan Ruang) yaitu hanya menyediakan $11 \%$ ruang terbuka untuk kawasan kulinernya. Pembangunan kawasan ini merupakan RTH (Ruang Terbuka Hijau)

2. Pembangunan kawasan kuliner yang berdekatan dengan Saluran Udara Tegangan Tinggi (SUTET) melanggar Peraturan Daerah No. 8 Tahun 2007 mengenai Ketertiban Umum di DKI Jakarta pada pasal 36. Menurut pemerintah DKI Jakarta dalam website resminya peruntukan lahan pada kawasan kuliner ini berada di zona khusus yang diprioritaskan sebagai lahan terbuka hijau. Namun pihak DPRD meminta PT Jakarta Propertindo menghentikan proyek tersebut karena dinilai berdiri diatas zona hijau dan berdekatan dengan saluran udara tegangan ekstra tinggi (SUTET) dan tidak menyesuaikan standarisasi $30 \%$ peruntukan lahan hijau.

Permasalahan terkait mengenai penyalahgunaan lahan yang tidak digunakan sebagaimana mestinya memberi pengertian bahwa pentingnya komitmen pemerintah dalam pengendalian dan penggunaan Lahan Terbuka Hijau (RTH). Peran masyarakat sekitar juga penting dalam menjaga keberlangsungan $\mathrm{RTH}$, sebagai pelaku utama yang dapat secara langsung menjaga, menikmati dan merasakan mafaat dari RTH tersebut. Dalam perwujudan proporsi RTH $30 \%$ dari luas wilayahnya memerlukan perencanaan yang komprehensif dari kebijakan yang terkait. Sehingga kebijakan yang diimplementasikan nantinya dapat berlangsung dengan efektif dan efesien. Pemerintah membuat regulasi untuk diterapkan pada sesuatu yang berkaitan dengan peraturannya.

\section{DAFTAR PUSTAKA}

Asharsinyo, D. F., Hanafiah, U. I. M., Mustafa, M., \& Isa, M. H. M. (2019). Degree Level of Publicness Through Meaning of Public Sphere In Bandung City, West Java, Indonesia. 3 rd International Conference on Architecture and Civil Engineering (ICACE), 636, 1-10.

https://doi.org/10.1088/1757899X/636/1/012021

Butudoka, Z. (2005). Evaluasi

Pemanfaatan Ruang Dan Struktur

Tata Ruang Wilayah Kabupaten

Tolitoli. SMARTEK, 3(4), 245-254. http://jurnal.untad.ac.id/jurnal/index.p hp/SMARTEK/article/view/373/312

Dyah Prinajati, P. (2019). Analisis Ruang Terbuka Hijau Terhadap Penyerapan Emisi Karbondioksida. Jurnal

Envirosan, 2(1), 34-41. https://doi.org/10.31848/ejtl.v2i1.276

Hakim, A. H. (2020). Kajian Perilaku Wisatawan dan PKL di Lapangan Merdeka Bengkulu Pada Fase Normal Baru. Jurnal Pengembangan Kota, 8(2), 188-199. https://doi.org/10.14710/jpk.8.2.188199

Hantono, D. (2019). Pasar Informal dan Wajah Kota di Indonesia. In Antologi Kota Indonesia \#2 (pp. 131-144). Omah Library.

Hantono, D., Sidabutar, Y. F., \& Hanafiah, U. I. M. (2018). Kajian Ruang Publik Kota Antara Aktivitas dan Keterbatasan. Langkau Betang: Jurnal Arsitektur, 5(2), 80-86. https://doi.org/10.26418/lantang.v5i2. 29387

Prayogi, L., \& Hantono, D. (2018). Bus Rapid Transit-oriented Development: 


\begin{abstract}
A Review of Built Environment Qualities Potentially Triggering Bus Rapid Transit Passengers' Modal Shift. International Journal of Engineering Research and Technology, 7(08), 302-305. https://www.ijert.org/bus-rapidtransit-oriented-development-areview-of-built-environmentqualities-potentially-triggering-busrapid-transit-passengers-modal-shift
\end{abstract}

Sari, Y., Hantono, D., \& Susilowati, E. (2017). Value Management di Pengembangan Real Estat Surabaya Berdasarkan Persepsi Praktisi Pengembang Real Estat. Arsitektur UMJ Press.

Sidabutar, Y. F., Sirojuzilam, Lubis, S., \& Rujiman. (2018). The Influence of Building Quality, Environmental Conditions of Historical Building and Community Participation to Cultural Tourism in Medan City. International Journal of Civil Engineering and Technology (IJCIET), 9(3), 259-270. http://www.iaeme.com/MasterAdmin/ UploadFolder/IJCIET_09_03_028/IJ CIET_09_03_028.pdf

Sugiyono. (2018). Metode Penelitian

Kuantitatif, Kualitatif, dan $R$ dan D. CV. Alfabeta. 